\title{
Stress, Strain-Rate Analysis of Sub-Surface Driveway Plants
}

\author{
Peter R. Greene ${ }^{1} \&$ Virginia A. Greene ${ }^{2}$ \\ ${ }^{1}$ B.G.K.T. Consulting Ltd. Bioengineering, Huntington, 11743, New York, USA \\ ${ }^{2}$ VGA, Architect, PC, Chicago, IL 60604-2001, USA \\ Correspondence: Peter R. Greene, B.G.K.T. Consulting Ltd. Bioengineering, Huntington, New York. Tel: \\ 1-631-935-5666. E-mail: prgreeneBGKT@gmail.com
}

Received: May 9, 2016 Accepted: May 1, $2017 \quad$ Online Published: June 25, 2017

doi:10.5539/jps.v6n2p55 URL: https://doi.org/10.5539/jps.v6n2p55

\begin{abstract}
Sub-surface driveway plants are strong enough to penetrate a macadam surface of thickness $7-9 \mathrm{~cm}$. The mechanics of how the Taraxacum officinale accomplishes this feat remain a mystery. Using the Maxwell model for pavement yielding over time, data are presented which may shed some light on this phenomenon. The post-buckling behavior of the plant stalk is quantified. Euler bending and buckling theory enables calculation of the cellular stress field, compared to turgor pressure, indicating impending cell buckling. Post-buckling plastic strain of the plant stem is $19 \%$. At the cell wall, the stress concentration factor is 3-times greater than the applied external field, so the cell's internal turgor pressure is overwhelmed by imposed external stress. An Impulse Integral is developed for the surface whereby the product of applied FORCE times TIME is CONSTANT, in order to produce a given amount of surface deflection. Taraxacum officinale stems and leaf stalks are strong enough, in buckling mode, to lift and push apart the fractured macadam crater through which they erupt, but not strong enough to initially crack the surface. The purpose of this work is to determine the mechanisms underlying this unusual plant survival phenomenon, backed by quantified data.
\end{abstract}

Keywords: bending-buckling, Young's modulus, stress-strain, cell turgor, plant mechanics, mechanosensing, viscoelasticity, enhanced growth rates, Taraxacum officinale

\section{Introduction}

This paper deals with the interesting topic of how Taraxacum officinale plants manage to grow through apparently impenetrable materials such as asphalt-macadam, Figure 1. Commercial products from this plant include latex, and various pharmaceuticals (Kristo et al., 2003). Studying plant biomechanical properties, it is possible to make some important conclusions about plant and perhaps animal "mechanosensing" at the cellular level, based on the imposed external uni-axial stress field caused by buckling and bending the flower and leaf stems, compared to the cell's turgor pressure (Baskin \& Jensen 2013; Dumais 2013). The fact that a plant can push through a solid surface suggests impressive biomechanical capabilities worthy of study.

\subsection{Literature Review}

Niklas \& Paolillo (1998) report measurements of Taraxacum stems under tension, comparable to the compressive experiments reported here. Cao et al. (2015) report that collagen materials grow in response to an increase in hydrostatic pressure. Niklas et al. (2009) discuss the mechanical bending moment of various types of tree leaves, relevant to the "robust" stress-enhanced leaf stems reported here. Ennos et al. $(1993 ; 2003)$ measure the mechanical properties of stems from sedge and sunflowers. Lintilhac (2014) reviews cell growth response to mechanical stress. Greene \& Greene $(2015,2016)$ report measurements of plant mechanics cracking a macadam surface. They observe that the surface is visco-elastically bent upwards into a dome, then the partially cured macadam cracks, usually into 8 pie-shaped segments, over a circular area approximately 3 -inches $(7-9 \mathrm{~cm})$ in diameter. Subsequently the developing Taraxacum stems and leaf stalks lift and push aside the 8 segments. It is likely the Taraxacum tap root is responsible for this initial penetration, constantly pushing upwards, visco-elastically bending the surface upwards, and in some cases cracking the asphalt-macadam. Roots can exert a pressure ahead of the tip, as great as the cell turgor pressure (25 to 80 p.s.i.). De Langre (2012) investigates plant response to wind loads. Silverberg et al. (2012) present experimental and theoretical results on root buckling in plants. Latz et al. (2008) and Kutschera \& Niklas (2013) report cell "mechanosensing" in response to external stresses. 


\section{Materials \& Methods}

\subsection{Bending, Buckling, Post-buckling}

The hypothesis is that a slow and steady vertical force will cause bending, yielding, and cracking of the macadam surface over a time scale of 6 months. Thus, experiments presented here are divided into two parts those on the plants, and those on the driveway surface. The Taraxacum buckling and bending procedures for flower stems and leaf stalks are described in Greene \& Greene (2015). Experimental results for stem and leaf buckling are shown in Figure 2. The inset schematic in Figure 2 shows buckling of a column of length $\mathrm{L}$ with axial force F. The "post-buckling" phase of plant stems is shown in Figure 7, 8. Buckling and bending experiments on the Taraxacum and Hypochaeris are done in vitro.

\subsection{Asphalt-macadam Deflection Experiments}

The experiments on the driveway material measure the force and integrated pressure required to break the 3 -inch thick $(7-9 \mathrm{~cm})$ macadam. This is calculated from 2 vertical deflection experiments, Figure 3, during the month of October 2014, 6 months after the driveway dandelions first appeared in April 2014.

\subsection{Exp. 1}

The load-deflection test is performed on the $8 \mathrm{~cm}$ thick partially cured macadam surface, 1 year after the macadam is steam rolled into place in compression, Oct. 2014. In order to determine its properties, a $200 \mathrm{lbf}$ $\left(880 \mathrm{~N}\right.$.) weight is arranged to push downward over a $4 \mathrm{sq}$. in. area $\left(25 \mathrm{~cm}^{\wedge} 2\right)$ measuring 2 " x $2 "(5 \mathrm{~cm} \times 5 \mathrm{~cm})$ which subsequently results in a $1 "(2.5 \mathrm{~cm})$ plastic depression downward, as shown in Fig. 3. This deflection occurs slowly and steadily over 30 days. The imposed vertical surface pressure is 50 p.s.i. $(350 \mathrm{kPa})$. In engineering terms, this is a normalized plastic strain-rate $\boldsymbol{\varepsilon} / \boldsymbol{\sigma}=(\mathbf{1} / \boldsymbol{\sigma})[\mathbf{d} \boldsymbol{\varepsilon} / \mathbf{d t}]=\mathbf{8 \%} / \mathbf{y r} / \mathbf{p s i}$. Exp. 2 - A second similar load-deflection creep rate test is performed, using much greater weights over a larger surface. A $2,000 \mathrm{lbf}$ weight $(8,800 \mathrm{~N})$ is loaded over a $5 "$ x $5 "(13 \mathrm{~cm} \mathrm{x} 13 \mathrm{~cm})$ area of $25 \mathrm{sq}$. in. $\left(170 \mathrm{~cm}^{\wedge} 2\right)$ resulting in a $1 / 2$-inch depression $(1.3 \mathrm{~cm})$ in the surface during the ensuing 7 days. This amounts to a normal surface pressure of 80 p.s.i. $(560 \mathrm{kPa})$. The plastic strain-rate is given by the normalized equation $\boldsymbol{\varepsilon}^{\prime} / \boldsymbol{\sigma}=(\mathbf{1} / \boldsymbol{\sigma}) \times[\mathbf{d} \boldsymbol{\varepsilon} / \mathbf{d t}]=\mathbf{9 \%} /$ yr / psi. From these measurements, the plastic strain-rate constituitive relation for partially cured macadam results:

$$
\varepsilon(\mathrm{t})=\mathrm{dz} / \mathrm{d} 0=-8.5 \% \text { [ per yr. per p.s.i. ] } \mathrm{x} \sigma \text { [p.s.i.] } \mathrm{t}[\mathrm{yr}] /(\mathrm{d} 0 / 3 ")^{\wedge} 3 \quad \text { Eq. } 1
$$

For a surface of thickness $\mathbf{d} \mathbf{0}$ [ in. ], the vertical deflection $\mathbf{z}(\mathbf{t})$ over time is given by:

$$
\mathrm{z}(\mathrm{t})[\mathrm{in} .]=-8.5 \% \mathrm{xd} 0 \text { [in.] } \mathrm{x} \sigma[\text { p.s.i. }] \mathrm{xt}[\mathrm{yr}] /(\mathrm{d} 0 / 3 ”)^{\wedge} 3 \quad \text { Eq. } 2
$$

\subsection{Thickness Variations}

The difference between a 2.5 " and 3.5 " (6 to $9 \mathrm{~cm}$ ) surface (this degree of variability one locale to the next is typical for a 3" $(8 \mathrm{~cm})$ paving) is given by the dimensionless term $(\mathbf{d o} / 3 \text { " })^{\wedge} 3$ in Eq. 2 , showing that the expected deflection can vary by a factor of 0.58 to 1.59 compared to the deflection of a standard $3 "(8 \mathrm{~cm})$ driveway surface. Thus, $1 / 2$ inch $(1.3 \mathrm{~cm})$ one way or another can make a $+/-50 \%$ difference in the surface strain-rate. It is important to quantify the surface properties because these are a direct indication of the forces generated by the sub-surface plants.

\section{Results}

\subsection{Taraxacum and Hypochaeris Plants}

As shown in Figure1 below, buckling and bending measurements on the flower stalk and leaf stems reveal that a typical 8-leaved 2-stem dandelion plant can vertically lift a total of $3 \mathrm{lbf}$. $(1.4 \mathrm{Kg})$. A more robust plant, the Hypochaeris, also fractures the surface, with 3 flower stems, capable of lifting overhead a remarkable total of 18 lbf. $(8.2 \mathrm{Kg})$. The displaced 3-inch diameter $(7-8 \mathrm{~cm})$ area of macadam weighs approximately 2 to 3 newtons ( 0.7 to $1.0 \mathrm{lbf}$ ) so either plant is strong enough to lift and push aside the macadam segments, but neither is strong enough to visco-elastically bend and then crack the surface in the first place. Only the plant's tap root, essentially a wooden cylinder measuring 1/2-inch to 5/8-inch in diameter $(1-2 \mathrm{~cm}), 3$ " to 4" long ( 8-10 cm), might puncture the surface. Each year, the tap root survives the Winter, then during the Spring, the perennial dandelion stalks and stems return, radiating from the top of the tap root surface, branching out of the upper $20 \%-30 \%$ of the tap root cylinder. 


\subsection{Thermal Cure Rate}

In May of 2014, 21 dandelion plants are observed to penetrate a 3" $(8 \mathrm{~cm})$ macadam surface, Figure 1. At this point in time, the surface is 6-months old. Colleagues in Germany and the U.K. (countries with colder average temperatures) report observing similar sub-surface phenomena, for several different types of plants. Figure 1 below shows the Taraxacum officinale plant, having just penetrated the macadam surface, with the characteristic 8 -segment volcano-like crater created by the plant, and the plant's "robust" (un-serrated) vertical leaves.

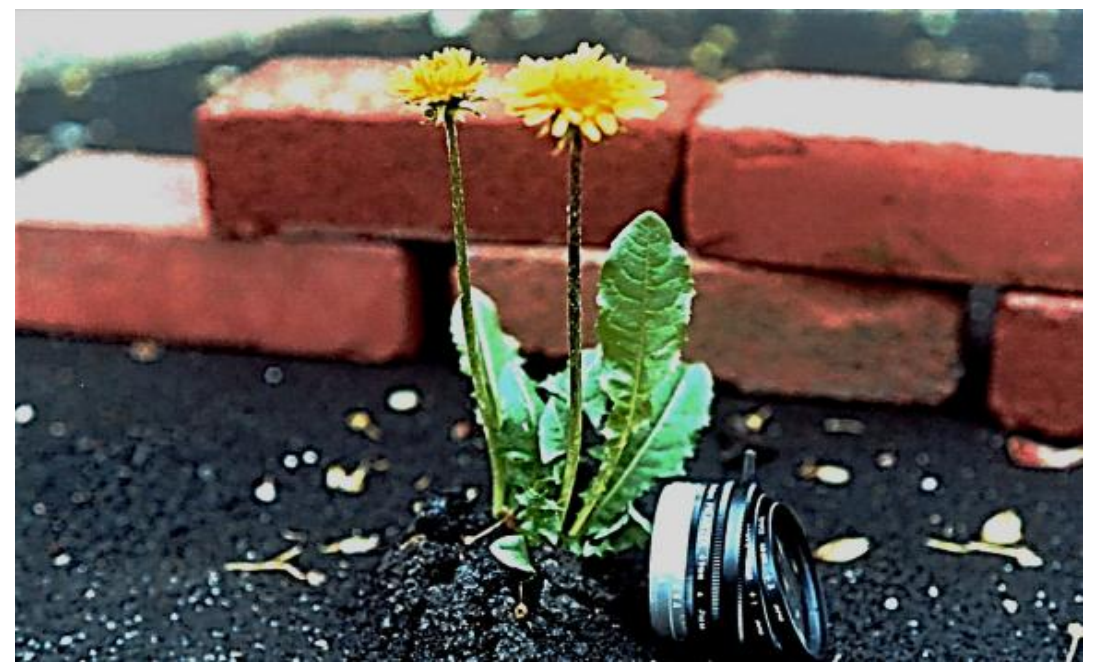

Figure 1. The plant is strong enough to penetrated a 3-inch $(6-8 \mathrm{~cm})$ thickness of macadam. A +2.00 diopt. "portrait lens" is used to photograph the "robust" Taraxacum officinale plant at a distance of 16-inches.

\subsection{Stem Buckling Load}

Experimental results for stem buckling (diamond symbols) are shown in Figure 2 below. The inset schematic in Figure 2 shows buckling of a column of length $\mathrm{L}$ with axial force F. Buckling and bending experiments on the Taraxacum and Hypochaeris are done in vitro. Theoretical buckling results (App. I) from the Taraxacum are shown in Figure 2 below (solid line). Measured values of stress allow calculation of the matrix force field surrounding cells in the plant tube wall, due to bending and buckling deflection at the inner and outer periphery of the flower and leaf stalks.

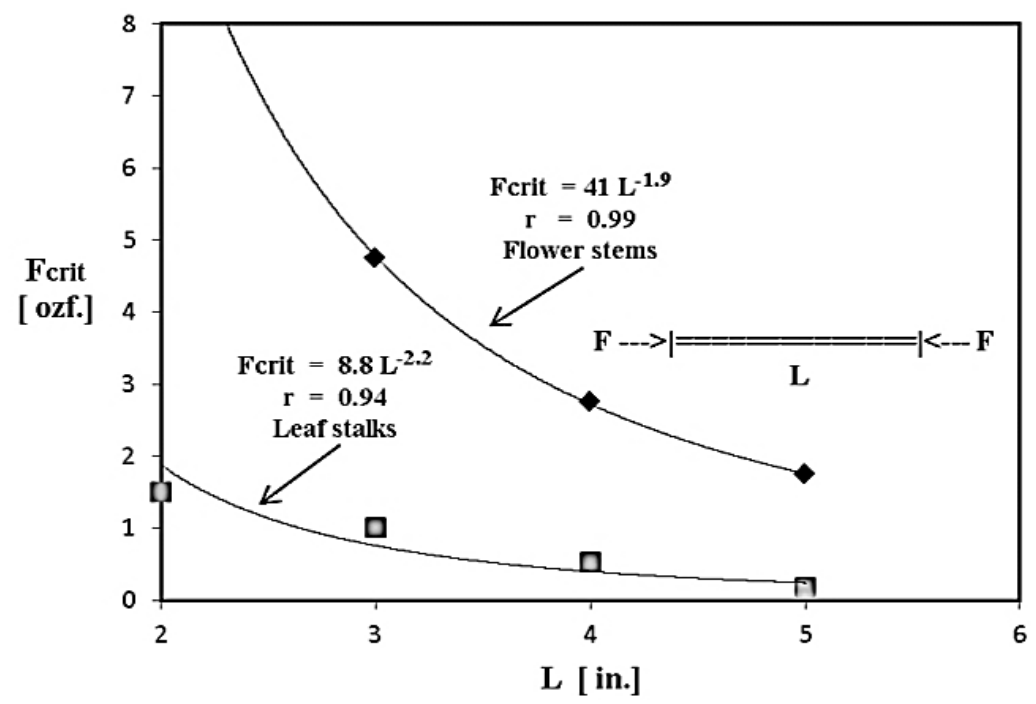

Figure 2. Stem buckling and leaf buckling data, confirming the Euler buckling exponent as -1.95, compared with -1.96 , using the logarithm technique. Theory predicts the exponent should be -2.0. Inset shows buckling load F applied to a column of length $\mathrm{L}$ 


\subsection{Leaf Buckling Load}

Figure 2 above shows Taraxacum leaf buckling data (square symbols). Niklas et al. (2009) discuss the mechanical bending moment of various types of tree leaves. Theory predicts the exponent should be -2.0 for both the flower stalks and the leaf stems. -1.95 to -2.23 exponents are observed experimentally here.

\subsection{Experimental Strain-rate}

Figure 3 below shows a $5 \mathrm{~cm}$ x $5 \mathrm{~cm}$ (2-inch by 2 -inch) crater or miniature pothole, $2.5 \mathrm{~cm}$ (1-inch) deep is formed during the month of October 2014, resulting from a $880 \mathrm{~N}$. (200 lbf) load applied over a 30-day period. At this point in time, the macadam surface has been in place for approximately 1 year. The surface was observed slowly deflecting downward at a constant rate over an interval of 4 weeks.

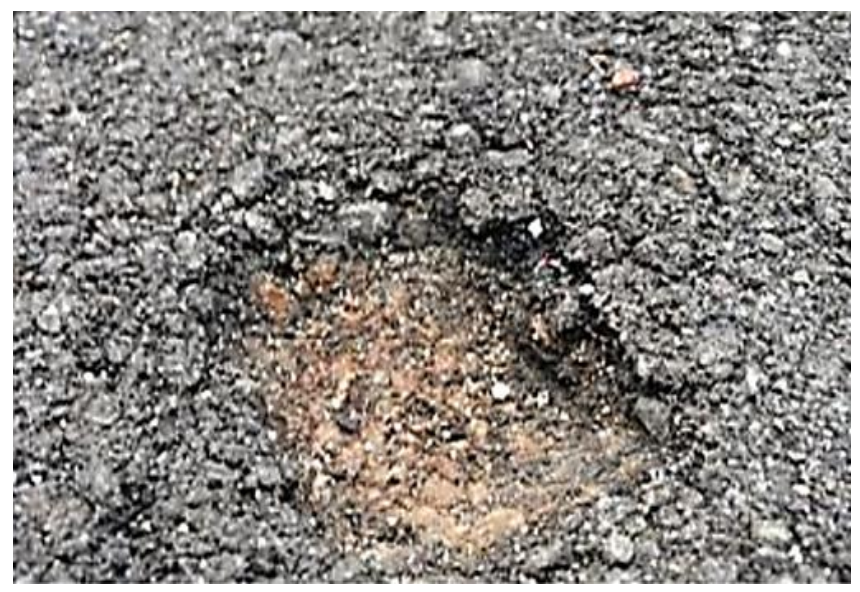

Figure 3. A $5 \mathrm{~cm} \times 5 \mathrm{~cm}$ (2-inch by 2-inch) crater or miniature pothole, $2.5 \mathrm{~cm}$ (1-inch) deep is formed during the month of October 2014, resulting from a $880 \mathrm{~N}$. (200 lbf) load applied over a 30-day period

\subsection{Maxwell Strain-rate model}

The 2-element viscoelastic Maxwell model used to describe the strain-rate response of partially cured macadam is shown in Figure 4 below. Using this model, only 1-parameter is needed to describe the surface strain-rate, the dashpot viscosity coefficient, with units of [\% strain / yr / p.s.i.]

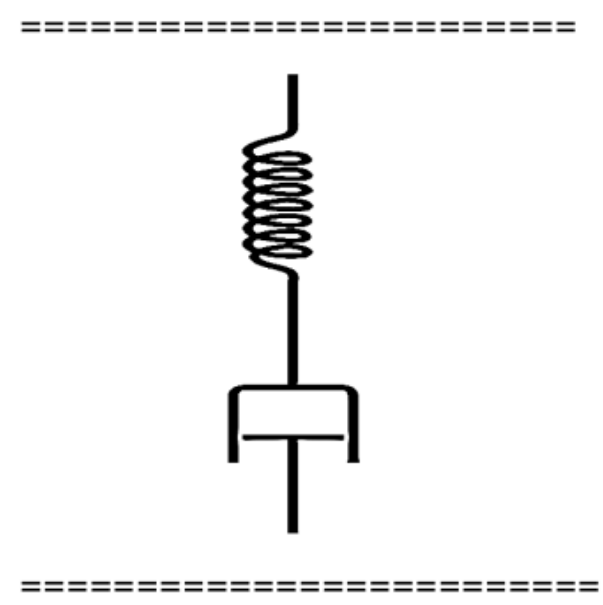

Figure 4. The 2-element viscoelastic Maxwell model is used to describe the strain-rate response of partially-cured macadam. 1-parameter describes the surface strain-rate, the dashpot viscosity coefficient [\%/yr/p.s.i.]

\subsection{Plant Young's Modulus}

The Hypochaeris radicata (catsear), a wild dandelion plant with much stronger flower stalks, essentially 3/16" $(5 \mathrm{~mm}$ ) diameter balsa wood dowels, easily manages to penetrate the $8 \mathrm{~cm}$ thick macadam surface, capable of 
lifting 17-18 lbf. (70-80 N) in vitro. The original plants in situ are capable of greater forces in vivo. Buckling and bending experiments on the Hypochaeris stems in vitro determine Young's modulus at E $=1600$ to $1700 \mathrm{MPa}$ respectively in compression, compared with 3 to $14 \mathrm{MPa}$ for the Taraxacum tube wall. The Euler equations for buckling and bending of tubes and rods are evaluated (Appendix I). The Taraxacum compression values measured for the stems are within a factor of 3 of those reported by Niklas \& Paolillo (1998) for inflated Taraxacum flower stems in tension.

\subsection{Cellular Transmural Pressure}

Figure 5 below is a schematic of transmural pressures encountered by a cell in a uni-axial stress field. The transverse radial strain arises from the Poisson effect, where $\mathrm{v} \sim 0.5$ for incompressible materials, $\mathrm{v} \sim 0.3$ for wood.

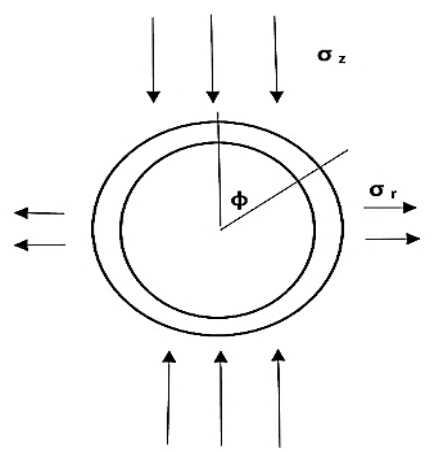

Figure 5. Schematic of transmural stresses encountered by a cell in a 2D uni-axial stress field. Transverse radial stress-strain arises from the Poisson effect. Stress concentration factor is 3.0 at $\phi=90^{\circ}$.

\subsection{Stress and Pressure Distribution}

Figure 6 below is a polar plot of compressive stress around the cell periphery, showing a maximum of $3 x$ amplification at the equator, and a minimum of $-1 \mathrm{x}$ at the poles. The stress field is caused by far-field anisotropic forces arising from buckling and bending of the plant stem. The local hydrostatic pressure increase is an average of the 3 principle stresses, causing the cell transmural pressure to reverse sign over some regions of the cell surface. The extent this influences various ion fluxes across the cell membrane is yet to be determined. Cao et al. (2015) report that collagen materials grow in response to an increase in hydrostatic pressure. The $+3 x$ stress concentration factor greatly increases the possibility that the cell's turgor pressure will be overwhelmed by the external $+1 \mathrm{x}$ external uni-axial stress field.

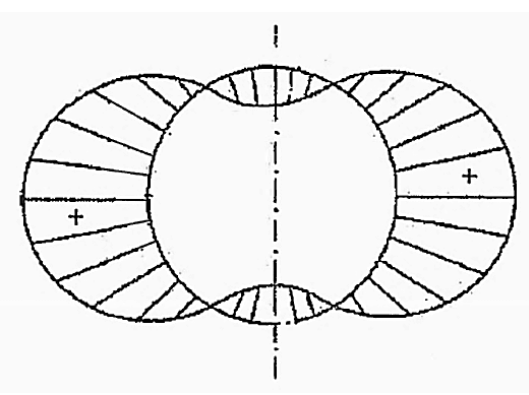

Figure 6. Polar plot of compressive stress around the cell periphery, showing a maximum stress concentration factor of $+3 x$ at the equator, and a minimum of $-1 x$ at the poles. Stress field is caused by far-field anisotropic forces arising from buckling and bending of the plant stem, Figure 5. Local hydrostatic pressure increase is an average of the principle stresses, causing the cell's transmural pressure to reverse in some geographical areas.

\subsection{Stalk Buckling}

Figure 7 below shows the characteristic S-shaped post-buckling configuration of the Taraxacum flower stalk after penetrating the surface, indicating the stalk was buckled under axial load during growth while penetrating the macadam. 


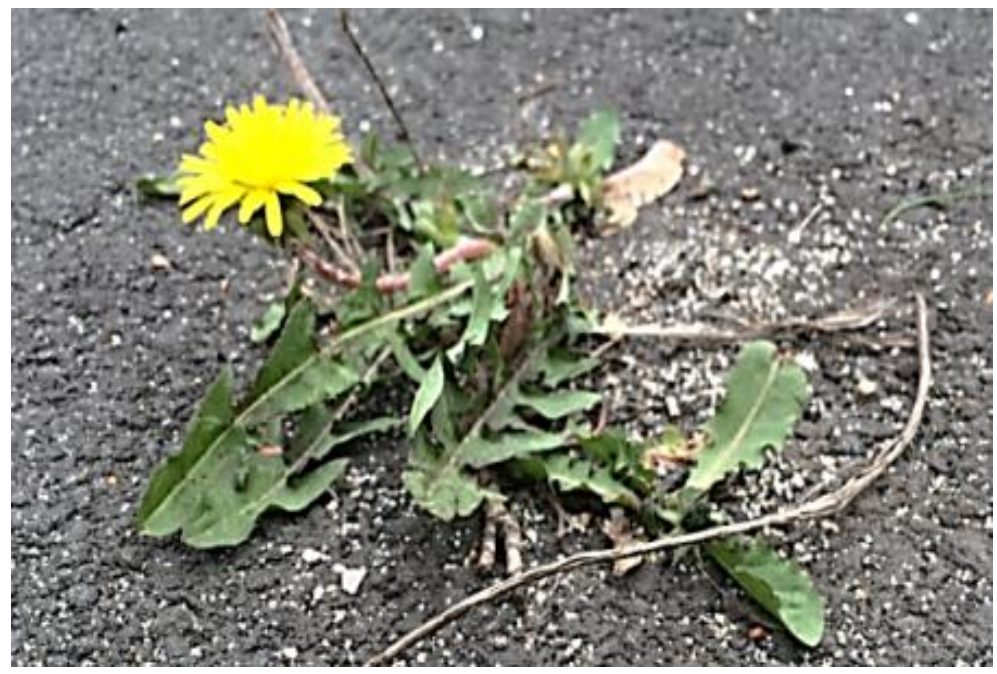

Figure 7. S-shaped "post-buckling" configuration of the Taraxacum flower stalk after clearing the surface indicates the stalk buckled, under axial load during growth, while pushing aside the macadam. This second-order buckling configuration is 4-times stronger than the first-order mode

\subsection{Stem Post-buckling}

Once buckled, the stem remains in the sigmoidal configuration, after the overhead load is removed. Post-buckling plastic strain is estimated at 19\%, Figure 7 above, based on radius of curvature and tube outer diameter (Greene, 1985). The plant cells are embedded in a cellulose matrix, so that when plastic failure of the stem occurs, at the inner radius, the cells are compressed, considerably more than 19\%, according to their relative volume fraction in the matrix. By comparison metals and polymers yield plastically at $4 \%$ to $10 \%$ axial strain.

\subsection{Enhanced Growth Rates}

Figure 8 below shows that during Year II, May of 2015, the Taraxacum returns to last year's craters, considerably more prolific. Figure 8 shows a 15 to 16 stem plant, stemming from last year's tap root at this site, which produced only a 2 stem plant in 2014. Another plant produces 8-9 stems from a tap root which last year had only 3 flowers.

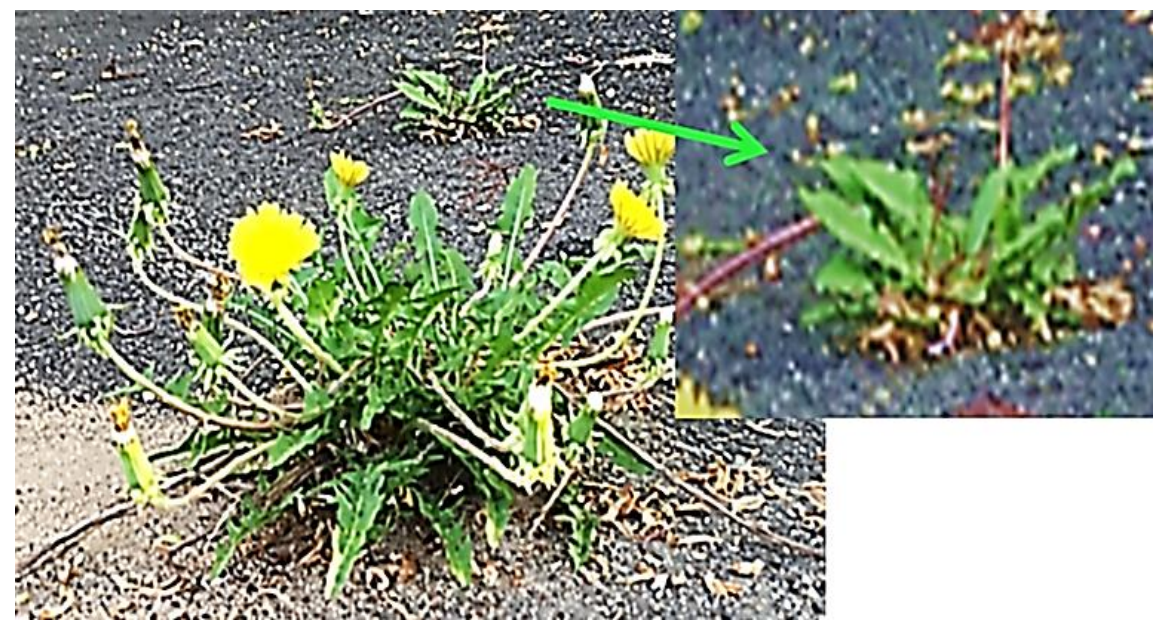

Figure 8. The Taraxacum regrows from last year's craters. Here, a 15 to 16 stalk plant is observed, stemming from last year's tap root at this site, which produced a 2 stem plant the year before. Inset shows wide un-serrated "robust" leaves of the Taraxacum plant in background 


\subsection{Crater Vent Segments}

Experimentally, these driveway plants crack a partially cured surface in 0.1 to $0.3 \mathrm{yr}$., when the plate is bent upwards by just $1 / 3$ of its thickness. During the period Nov.-Dec. 2014, after the first frost, the plants die and wither. Subsequently, the 8 pie-shaped segments of the volcano-like crater fold downward, partially closing the vent. These 8 segments are closed further by winter snow loading.

\subsection{Robust Plant Development}

During the 2nd year, puncturing the surface is mechanically easier for the plant, because the surface was pre-cracked the year before. Like human weight-lifters, it seems that plants "bulk-up" in response to stress, as shown in Figs. 1, 4, and 8. In particular, the original serrated leaves instead develop a stronger full-leaved configuration under stress, without serrations, Figure 1 and 8.

\section{Discussion}

\subsection{Cell Mechanics}

The phenomenon of "mechanosensing", whereby cells and fibers grow preferentially in response to stress, is discussed by Borau et al. (2014), Coutand et al. (2010), and Reilly \& Engler (2010). In order to meet the weight-lifting challenge posed by the surface, the leaves and stems appear to strengthen their tube walls, to meet the demands of the situation, increasing stem diameter and wall thickness, possibly increasing cell turgidity pressure, perhaps increasing the cell reproduction, (Pickett-Heaps \& Klein, 1998; Iddles, 2003).

\subsection{Light and Temperature Cues}

Buried under the macadam, the plants have no light-cues from above, only temperature-cues, so the plant may be deceived, (because it is warmer under the macadam due to absorbed radiant energy from sunlight and the heat capacity of the surface) that Spring is arriving in February or March, instead of April. This factor gives the plant extra growth time, necessary to visco-elastically buckle the driveway upwards, ultimately cracking the surface.

\subsection{Stress Concentration Factor}

At the cell wall, the compressive stress due to the external field is magnified 3-times, i.e. there is a "stress concentration factor" of 3.0. In practical terms, this means that the measured axial compressive stress in the celluslose matrix of 23 p.s.i. ( at maximum buckling load ) is augmented to 70 p.s.i. at the cell wall, comparable to the $40-80$ p.s.i. internal cellular turgor pressure reported by Schopfer (2006) typical for plant cells. Dumais (2013) discusses the effect of such stress fields on cell deformation. Baskin \& Jensen (2013) report the effects of anisotropic stress (i.e. uni-directional stress) on cell growth in stems.

\subsection{Stem Buckling}

It is likely that macroscopic stem-buckling, as shown in Fig. 4, is simultaneously a direct consequence of microscopic cell buckling, or even cell rupture. Measurements and calculations presented here indicate that the external uni-axial stress field, imposed during the post-buckling phase, is sufficient to overwhelm the cell's internal turgor pressure, reversing the cell membrane transmural pressure, causing impending cellular buckling. The post-buckling stem configuration indicates that irreversible compression has done damage to the plant tube wall. The post-buckling plastic strain is estimated at 19\%, an average value throughout the cellulose matrix, probably much greater locally at the cellular level, after compensating for matrix stiffness effects, (Kutschera \& Niklas, 2013).

\subsection{Mechanosensing}

The physical stress, an anisotropic (one dimensional) stress field, imposed on the tube wall is significant. The annular area of a $6.4 \mathrm{~mm}$ O.D. (outside diam.) stalk, with I.D. $=4.8 \mathrm{~mm}$ (inside diam.) supports the axial load. At a maximum buckling load of $2.2 \mathrm{~N}$. for the shortest columns measured, this amounts to a wall stress of $s=$ $163 \mathrm{kPa}$, (23 p.s.i.), approximately 1.5 atmospheres, resulting in $\boldsymbol{e}=5.8 \%$ compressive strain. Comparably, Arnoldi et al. (2000), report cell turgor pressure in the same range, 85 to $150 \mathrm{k} \mathrm{Pa}$, (15 to 20 p.s.i.) measured in bacteria cells.

\subsection{Plant-cell Turgor}

Internal cell pressure (turgor) for plants is generally higher, in the range $300-600 \mathrm{k} \mathrm{Pa}$ (40 to 80 p.s.i.), Schopfer (2006). This remarkable plant wall stress level, caused by the overhead loading, is unusual. Internal stress at peak buckling load is calculated as $s>1.4 \mathrm{M} \mathrm{Pa}$, more than 10 atmospheres (Hypochaeris). Compressive wall stress can be greater than the cell turgor pressure, typically 100 to $200 \mathrm{kPa}$ (15 to 30 p.s.i.) for animal cells; Schopfer (2006) reports $300-600 \mathrm{kPa}$ ( 40 to 80 p.s.i.) for peas; Kutschera \& Niklas (2013) report 
$500 \mathrm{kPa}$ (70 p.s.i.) for sunflowers. This level of stress will compress the plant cells longitudinally, Figure 5, 6 .

\subsection{Cell Compression}

According to our measurements, the axial tube-wall stresses caused by bending and flexing during buckling are comparable to cell turgor pressure. This is particularly important, after compensating for the 3-fold stress concentration factor at the cell wall. In other words, the environment can, on occasion, "put the squeeze" on the cells, causing the cell transmural pressure to reverse sign regionally over the surface of the cell, as shown in Figure 6, overwhelming the cell walls with external compressive stress greater than their turgor pressure. Dumais (2013) discusses the effect of such stress fields on cell deformation. Baskin \& Jensen (2013) report the effects of anisotropic stress (i.e. uni-directional) on cell growth in stems.

\subsection{Transmural Pressure}

Local hydrostatic pressure, external to the cell, is the average of the 3 orthogonal stresses. Cao et al. (2015) measure collagen materials growing in response to an increase in hydrostatic pressure. Linilhac (2014) discusses the mechanics of cell growth and mechanosensing. The extent to which the local reversal of transmural-pressure influences differential ion fluxes across the cell membrane is fundamentally important.

\subsection{Driveway Surface Mechanics}

Most plants, even the remarkably strong Hypochaeris (Greene, 2016), simply cannot, on their own, produce enough vertical force to crack the 3 -inch surface, so other factors must come into play during the winter months. Reasonable possibilities include frost heave of the surface, thermal expansion during the day from sunlight, thermal cycling (freezing and thawing) during the 24-hour day, and impending vertical buckling of the surface, due to accumulated in-plane compressive stress. Highways are known to buckle as a result of thermal expansion effects, so this phenomenon has some precedence in the literature.

\section{Conclusions}

\subsection{Maximum Vertical Plant Force}

Some driveway plants, during the growth phase, are remarkably strong, and this effect, coupled with the weaker than expected viscoelastic properties of a partially cured surface, may partially explain the ability of some plants to penetrate the driveway surfacing. Initial measurements suggested only a matter of grams (or ounces) as the vertical force generated by the plant, but experimental measurements presented here show the plants are capable of kilograms (or several pounds) of vertical force. Likewise, during steam rolling, the vertical surface forces were a matter of tons (or metric tons), but as measured here, just several kilograms (or tens of pounds) are required to fracture the surface, including the sustained time element.

\subsection{Required Rupture Force}

According to measurements reported here, there is a factor of $10 x$ discrepancy, i.e. a shortfall, between what the plant is capable of, and what is required to rupture the surface. Thus, it is important to quantify, to calibrate, the surface, because it is basically the "force-platform" against which the sub-surface plant pushes.

\subsection{Maxwell Strain-rate (Creep-rate)}

The prime result of the Maxwell dashpot model, Figure 4, and mechanical measurements of the driveway surface, is that $3 \mathrm{lbf}$. (1.4 Kg) of vertical force (available from one Taraxacum plant, as measured) over a time scale of 10-months will produce the same plastic deflection as $30 \mathrm{lbf}$. (14 Kg) (available from 3 Hypochaeris stems as measured) exerted over 1-month, approximately $1 / 8$-inch $(3 \mathrm{~mm})$. On a timescale of 24 hours, for this particular surface, approximately $1,000 \mathrm{lbf}(454 \mathrm{Kg})$ is required to deflect the surface by $1 / 8$-inch.

\subsection{Force-time Impulse Integral}

From these measurements, a useful "Impulse Integral" results, namely, that the product of applied FORCE times TIME is CONSTANT, (other things being equal, temperature, surface properties, etc.) in order to produce a given amount of surface deflection. McMahon \& Greene (1979) measure elastic surface stiffness, the compliance element in Figure 4, of various surfaces (athletic and otherwise), reporting values in the range 50,000 lbf/ft. to $100,000 \mathrm{lbf} / \mathrm{ft}$. ( $670 \mathrm{kN} / \mathrm{m}$ to $1,400 \mathrm{kN} / \mathrm{m}$ ). The Maxwell strain-rate constant and creep hardening rates will vary according to regional temperature throughout the year. The sustained time element may be the key to explaining this unique plant survival phenomenon.

How exactly the Taraxacum plant manages to accomplish its escape, buried under 3 " $(8 \mathrm{~cm})$ of macadam, is still unknown. So, the secrets of these remarkably strong plants remain a mystery for the time being. 


\section{References}

Arnoldi, M., Fritz, M., Bäuerlein, E., Radmacher, M., Sackmann, E., \& Boulbitch, A. (2000). Bacterial turgor pressure can be measured by atomic force microscopy. Phys Rev E. Jul, 62(1 Pt B), 1034-44. https://doi.org/10.1103/PhysRevE.62.1034

Baskin, T. I., \& Jensen, O. E. (2013). On the role of stress anisotropy in the growth of stems.J Exp Bot., 64(15), 4697-707. https://doi.org/10.1093/jxb/ert176

Beisman, H., Wilhelmi, H., Bailieres, H., Spatz, H. C., Bogenrieder, A., \& Speck, T. (2000). Brittleness of Twig Bases in the Genus Salix: Fracture Mechnaics and Ecological Relevance. Jour. Exp. Bot. 51(344), 617-633. https://doi.org/10.1093/jexbot/51.344.617

Borau, C., Kamm, R. D., García-Aznar, J. M. (2014). A time-dependent phenomenological model for cell mechano-sensing. Biomech Model Mechanobiol, 13(2), 451-62. https://doi.org/10.1007/s10237-013-0508-x

Cao, X., Xia, H., Li, N., Xiong, K., Wang, Z., \& Wu, S. (2015). Mechanical Refractory Period Of Chondrocytes After Dynamic Hydrostatic Pressure. Connect Tissue Res., 56(3), 212-8. https://doi.org/10.3109/03008207.2014.1001383

Coutand, C., Chevolot, M., Lacointe, A., Rowe, N., \& Scotti, I. (2010). Mechanosensing of stem bending and its interspecific variability in five neotropical rainforest species. Ann Bot., 105(2), 341-7. https://doi.org/10.1093/aob/mcp286

Dumais, J. (2013). Modes of deformation of walled cells. J Exp Bot., 64(15), 4681-95. https://doi.org/10.1093/jxb/ert268

Ennos, A. R. (1993). The Mechanics of Flower Stems of the Sedge Carex acutiformis. Ann. Botany, 72, 123-127. https://doi.org/10.1006/anbo.1993.1089

Fournier, M., Dlouhá, J., Jaouen, G., \& Almeras, T. (2013). Integrative biomechanics for tree ecology: beyond wood density and strength. $J$ Exp Bot., 64(15), 4793-815. https://doi.org/10.1093/jxb/ert279

Greene, P. R. (1985). Stress-strain behavior for curved exponential strips. Bull Math Biol., 47(6), 757-64. https://doi.org/10.1007/BF02469302

Greene, P. R. (2016). Vertical-Lift Potential of the Trapped Hypochaeris radicata (Catsear), a Phototropic Sub-Pavement Plant, Res Rev J Botanical Sci., 5(4),

https://www.rroij.com/open-access/verticallift-potential-of-the-trapped-hypochaeris-radicata-catseara-photo tropic-subpavement-plant-.php?aid=83488

Greene, P. R., \& Greene, V. A. (2015). Buckling, Bending, and Penetration Response of Taraxacum officinalae (Dandelions) to Macadam Loading. Australian J. Botany, 63(6), 512-516. https://doi.org/10.1071/BT15083

Iddles, T. L., Read, J., \& Sanson, G. D. (2003). Potential Contribution of Biomechanical Properties to Anti-herbivore Defense in Seedlings of Six Australian Rainforest Trees. Austr. J. Botany, 51, 119-128. https://doi.org/10.1071/BT02060

Kristo, T. S., Szoke, E., Kery, A., Terdy, P. P., Selmeczi, L. K., \& Simandi, B. (2003). Production and Characterization of Taraxacum Officinale Extracts Prepared by Supercritical Fluid and Solvent Extractions. Acta Horticulturae, Int'l. Soc. Hort. Sci., 597(1), 1.

Kutschera, U., \& Niklas, K. J. (2013). Cell division and turgor-driven stem elongation in juvenile plants: a synthesis. Plant Sci., 207, 45-56. https://doi.org/10.1016/j.plantsci.2013.02.004

Langre, E. (2012). Methodological advances in predicting flow-induced dynamics of plants using mechanical-engineering theory. J Exp Biol., 215(Pt 6), 914-21. https://doi.org/10.1242/jeb.058933

Latz, M. I., Bovard, M., VanDelinder, V., Segre, E., Rohr, J., \& Groisman, A. (2008). Bioluminescent response of individual dinoflagellate cells to hydrodynamic stress measured with millisecond resolution in a microfluidic device. J Exp Biol., 211(Pt 17), 2865-75. https://doi.org/10.1242/jeb.011890

Lintilhac, P. M. (2014). The problem of morphogenesis: unscripted biophysical control systems in plants. Protoplasma, 25l(1), 25-36. https://doi.org/10.1007/s00709-013-0522-y

McMahon, T. A., \& Greene, P. R. (1979). The influence of track compliance on running. J Biomech., 12(12), 893-904. https://doi.org/10.1016/0021-9290(79)90057-5

Niklas, K. J., \& Paolillo, D. J. (1998). Preferential States of Longitudinal Tension in the Outer Tissues of Taraxacum officinale (Asteraceae) Peduncles. Am. J. Bot., 85(9), 1068-1081. 
https://doi.org/10.2307/2446340

Niklas, K. J., Cobb, E. D., \& Spatz, H. C. (2009). Predicting the allometry of leaf surface area and dry mass. Am J Bot., 96(2), 531-6. https://doi.org/10.3732/ajb.0800250

Pickett-Heaps, J. D., \& Klein, A. G. (1998). Tip Growth in Plant Cells May be Amoeboid and Not Generated by Turgor Pressure. Proc. Roy. Soc. B, 265(1404), 1453-1459. https://doi.org/10.1098/rspb.1998.0457

Schopfer, P. (2006). Biomechanics of plant growth. Am J Bot., 93(10), 1415-25. https://doi.org/10.3732/ajb.93.10.1415

Silverberg, J. L., Noar, R. D., Packer, M. S., Harrison, M. J., Henley, C. L., Cohen, I., \& Gerbode, S. J. (2012). 3D imaging and mechanical modeling of helical buckling in Medicago truncatula plant roots. Proc Natl Acad Sci USA, 109(42), 16794-9. https://doi.org/10.1073/pnas.1209287109

Smith, V. C., \& Ennos, A. R. (2003). The effects of air flow and stem flexure on the mechanical and hydraulic properties of the stems of sunflowers Helianthus annuus L. J Exp Bot., 54(383), 845-9. https://doi.org/10.1093/jxb/erg068

Waghorn, M. J., \& Watt, M. S. (2013). Stand variation in Pinus radiata and its relationship with allometric scaling and critical buckling height. Ann Bot., 111(4), 675-80. https://doi.org/10.1093/aob/mct015

Appendix I. Euler Equations for Buckling and Bending of Columns and Beams

[1] Critical buckling load Fcrit is given by: (unclamped)

$$
\text { Eq. (1) } \quad \text { F crit }=\pi^{\wedge} 2 \times \mathrm{EI} /\left(\mathrm{L}^{\wedge} 2\right)
$$

where $\mathrm{F}$ crit $=$ axial buckling force, $\mathrm{E}=$ Young's modulus of elasticity, $\mathrm{I}=$ moment of inertia, $\mathrm{L}=$ column length.

[2] Beam bending deflection $\mathbf{d}$ is given by: (cantilevered)

$$
\text { Eq. (2) } \quad d=F \times L^{\wedge} 3 / 3 \text { ( EI ) }
$$

where $\mathrm{d}=$ lateral tip deflection, $\mathrm{F}=$ applied lateral force, $\mathrm{L}=$ beam length, $(\mathrm{E}$ and $\mathrm{I}$ as in Eq. 1)

Example: A practical example of plate strain-rate (using the Maxwell model, Figure 4) serves to illustrate: The Hypochaeris plant imposes an upwards vertical force of $18 \mathrm{lbf}(80 \mathrm{~N})$, as measured, over a surface area of $1 / 2$ in^2 $\left(1.5 \mathrm{~cm}^{\wedge} 2\right)$. This is a normal surface stress of 36 p.s.i. We would like to know how long it takes the Hypochaeris plant to crack the driveway, a $3 "(8 \mathrm{~cm})$ thick macadam surface. Vertical strain-rate $($ Eqs. 1,2$)$ is calculated as $8.5 \%$ x 3 " x 36 psi x 1 yr. $=9.2 \mathrm{in} / \mathrm{yr}$. $(23 \mathrm{~cm} / \mathrm{yr})$. Thus, this plant will take $0.3 \mathrm{yrs}$. to fully crack the surface, as observed.

[3] Moment of inertia I of a tube column or beam is given by: (neutral axis)

$$
\text { Eq. (3) } I=\pi \times\left(R^{\wedge} 3\right) \Delta R
$$

where $\mathrm{I}=$ moment of inertia of the tube, $\mathrm{R}=$ average tube radius, $\Delta \mathrm{R}=$ tube wall thickness

[4] Moment of inertia $I$ of a solid rod column or beam is given by: (neutral axis)

$$
\text { Eq. (4) } I=\pi \times R^{\wedge} \mathbf{4} / 4
$$

where $\mathrm{I}=$ moment of inertia for a solid rod, $\mathrm{R}=$ radius of the solid rod

[5] The moment of inertia $\mathbf{I}$ of a rectangular beam (plate) is given by:

$$
\text { Eq. (5) } I=(1 / 12) \times W \times d^{\wedge} 3
$$

where $\quad W=$ width, $\mathrm{d}=$ thickness.

\section{Copyrights}

Copyright for this article is retained by the author(s), with first publication rights granted to the journal.

This is an open-access article distributed under the terms and conditions of the Creative Commons Attribution license (http://creativecommons.org/licenses/by/4.0/). 